\title{
PERBEDAAN KINERJA PERTUMBUHAN EKONOMI PADA KUARTAL RAMADHAN DAN RATA-RATA KUARTAL DILUAR RAMADHAN DAN IDUL FITRI ${ }^{1}$
}

\author{
Dewi Muninggar Lintangjohor Sribanu \\ Departemen Ekonomi Syariah - Fakultas Ekonomi dan Bisnis - Universitas Airlangga \\ Email: Dewlintangjs@gmail.com \\ Eko Fajar Cahyono \\ Departemen Ekonomi Syariah - Fakultas Ekonomi dan Bisnis - Universitas Airlangga \\ Email: Ekofajarc@feb.unair.ac.id
}

\begin{abstract}
:
The purpose of this study was to find the difference of economic growth between quartal with Ramadhan and quartal outside of Ramadhan (the average). This study use quantitative methods using t-test, to find the comparison between the economic growth from quartal of Ramadhan and quartal outside Ramadhan. Our result find that economic growth in quartal of Ramadhan is higher than the average quartal outside Ramadhan, religious practice can affect individual behaviour and beliefs in a ways that have implications for economic performance. Economic growth in quartal of Ramadhan increase, because people tend to consume more than in other months.
\end{abstract}

Keywords: Economic Growth, Ramadhan and economy, The Effect of Holiday to Economy, GDP

I. PENDAHULUAN

Pertumbuhan ekonomi dapat menjadi indikator untuk melihat keberhasilan suatu Negara dalam melakukan pembangunan, termasuk mengenai pengentasan kemiskinan, pengangguran dan penyerapan tenaga kerja. Pada banyak Negara di dunia, salah satu syarat utama penurunan kemiskinan adalah pertumbuhan ekonomi. Salah satu aspek untuk melihat kinerja perekonomian adalah seberapa efektif penggunaan sumber daya yang ada, termasuk pada hal lapangan pekerjaan. Pertumbuhan ekonomi dan pengangguran memiliki hubungan karena penduduk yang bekerja berkontribusi dalam menghasilkan barang dan jasa, sedangkan pengangguran tidak memberikan kontribusi terhadap hal tersebut.

Okun (1962) secara empiris membuktikan hubungan antara tingkat pengangguran dan output, tergantung pada partisipasi di tempat kerja, tingkat waktu bekerja dan perubahan di produktifitas. Arthur Okun menemukan fakta bahwa apabila tingkat penganguran berkurang ketika tingkat pertumbuhan ekonomi tinggi, begitu pula sebaliknya tingkat pengagguran meningkat ketika pertumbuhan ekonomi rendah atau negatif (Soylu, O.B, Cakmak,I \& Okur, F: 2018). Secara teoritis, upaya pengentasan kemiskinan mensyaratkan adanya pertumbuhan ekonomi suatu Negara yang berkualitas. Pertumbuhan ekonomi yang berkualitas dapat

\footnotetext{
1 Jurnal ini merupakan bagian dari skripsi Dewi Muninggal Lintangjohor Sribanu, NIM: 041411433041, yang diuji pada tanggal 22 Januari 2019.
} 
Sribanu, et al/Jurnal Ekonomi Syariah Teori dan Terapan Vol. 6 No. 5 Mei 2019: 1007-1029; PERBEDAAN KINERJA PERTUMBUHAN EKONOMI PADA KUARTAL RAMADHAN DAN RATA-RATA KUARTAL DILUAR RAMADHAN DAN IDUL FITRI

diwujudkan melalui kebijakan perluasan kesempatan kerja dan mengurangi tingkat pengangguran serta memaksimalkan investasi yang produktif di berbagai sektor ekonomi. Menurut teori neo klasik, pertumbuhan ekonomi tergantung pada pertambahan penyediaan faktor produksi (sumber daya manusia dan akumulasi modal) dan tingkat kemajuan teknologi. Pertumbuhan ekonomi dapat mengentaskan kemiskinan dikarenakan dengan pertumbuhan ekonomi, kualitas pada berbagai sektor menjadi lebih baik (Jonaidi: 2012). Setiap Negara berusaha keras untuk mencapai pertumbuhan ekonomi yang optimal dan menaikkan mutu hidup dan kesejahteraan masyarakatnya.

Manusia diciptakan oleh Allah SWT sebagai khalifah dimuka bumi ini, bertugas memelihara dan memakmurkan sumber daya yang ada di bumi ini serta memanfaatkan segala yang ada untuk kemaslahatannya. Peran pemerintah daerah dalam menyukseskan pertumbuhan dan pembangunan ekonomi sangat dibutuhkan, setiap daerah dituntut untuk lebih mandiri dalam mebiayai kegiatan operasionalnya terutama dalam era otonomi luas ini dengan memanfaatkan sumber daya yang ada.

Pengukuran dalam perekonomian di suatu Negara adalah Produk Domestik Bruto (PDB). Produk domestik bruto mengukur aliran pendapatan dan pengeluaran dalam perekonomian suatu
Negara pada periode tertentu. Pertumbuhan ekonomi berkaitan dengan proses peningkatan produksi barang dan jasa dalam kegiatan perekonomian masyarakat. Untuk mengukur pertumbuhan ekonomi, nilai PDB berdasarkan harga konstan atau riil, sehingga angka pertumbuhan yang dihasilkan terjadi karena adanya pertumbuhan produksi (Mankiw, 2007). Jumlah nilai barang dan jasa akhir yang disediakan dari produksi, harus sama dengan nilai barang yang digunakan. Pendekatan yang dilakukan untuk mengukur produk domestik bruto ada 3 macam, yaitu pendekatan produksi, pendekatan pengeluaran dan pendekatan pendapatan.

Menurut Badan Pusat Statistik tahun 2010, yang saya unduh pada tanggal 19 September 2018 pada website Bps.go.id, tertera bahwa 207.176.162 jiwa masyarakat yang beragama muslim dari 237.641.326 penduduk Indonesia. Terdapat dua hari raya besar dalam Islam, yaitu hari raya Idul Fitri dan hari raya Idul 'Adha (Kurban). Idul Fitri terjadi setelah para umat Islam melakukan puasa ramadhan selama sebulan dan akan mengeluarkan amal atau zakat fitrah pada malam sebelum Idul Fitri, sedangkan Idul 'Adha jatuh pada hari kesepuluh dari bulan dzulhijah dan berlangsung selama empat hari. Pada saat itu, kaum Muslim biasanya akan menyembelih hewan kurban seperti kambing, sapi, domba atau unta tergantung pada wilayahnya dan 
Sribanu, et al/Jurnal Ekonomi Syariah Teori dan Terapan Vol. 6 No. 5 Mei 2019: 1007-1029; PERBEDAAN KINERJA PERTUMBUHAN EKONOMI PADA KUARTAL RAMADHAN DAN RATA-RATA KUARTAL DILUAR RAMADHAN DAN IDUL FITRI

dagingnya akan dikonsumsi oleh para anggota keluarga, tetangga dan orang yang membutuhkan. Kedua hari raya tersebut berdasarkan pada penanggalan kalender Islam atau Hijriyah, yang merupakan kalender bulan, bukan kalender Gregorian yang merupakan kalender matahari.

Pada beberapa negara, hari besar atau hari libur dapat memberikan pengaruh terhadap perekonomian yang berbeda-beda. Contohnya Ramadhan di berbagai negara Muslim di dunia, Lunar New Year, serta hari natal. Di Turki dan Pakistan, hari besar seperti ramadhan secara umum tidak berpengaruh terhadap inflasi nasional, tetapi berpengaruh pada inflasi di beberapa komoditas, sedangkan di Amerika, hari besar seperti Natal, Thanksgiving serta Hallowen tidak berpengaruh terhadap inflasi. Pengaruh itu disebabkan adanya pola perubahan konsumsi masyarakat pada beberapa komoditas tertentu yang pada akhirnya berpengaruh pada permintaan serta penawaran dalam komoditas tersebut. Tingkat konsumsi yang meningkat dapat mendorong kenaikan harga, sehingga pada akhirnya tingkat inflasi juga terdorong naik akibat dari kenaikan harga dari barang yang dikonsumsi tersebut.

Efek hari besar atau hari libur sudah di pelajari di Amerika Serikat, (Lakonishok dan Smidt: 1988) menjelaskan tentang pengaruh hari libur atau besar di amerika dan menemukan perbedaan antara hari libur dan diluar itu. Mereka menemukan bahwa sekitar setengah dari pendapatan keuntungan industri Dow Jones rata-rata terjadi pada 10 hari praliburan setiap tahun. Namun, pendapatan (pasar vang) pasca liburan tidak signifikan hingga tahun 1952. Hal ini berubah menjadi positif dan signifikan mulai dari tahun 1952 hingga 1986. Hasil ini di konfirmasi oleh peneliti lain, Ariel (1990), meneliti pendapatan pasar dan mendokumentasikan efek dari hari libur sehingga menemukan hasil yang signifikan. Ariel menunjukkan bahwa lebih dari sepertiga dari pengembalian positif setiap tahun dilakukan pada 8 hari sebelum hari libur dan pasar tutup. Selama periode pra liburan, harga saham naik dan memiliki frekuensi pengembalian positif yang jauh lebih tinggi terutama pada beberapa jam terakhir. Menurut Lakonishok dan Smidt (1988), tidak seperti anomali lainnya, efek dari hari libur dampaknya lebih terlihat dari waktu ke waktu. Dalam jurnal berjudul Investment Management and Financial Innovation oleh Wu Chongseng (2013) juga menuliskan bahwaMcGuinness dan Harris (2011) meneliti tahun baru China atau imlek dan efeknya pada pasar keuangan di Shanghai, Shenzhen dan hongkong. Pada tahun baru China, atau festival musim semi -hari libur terbesar di Chinamereka menemukan pengembalian postif dari saham di tiga hari sebelum hari libur dan sehari setelah hari libur. Lebih dari itu, efek yang diberikan berpengaruh pada 
semua sektor pasar yang ada di Shenzhen, Shanghai dan Hongkong. Chan, Khanthavit dan Thomas (1996) dalam jurnal Wu Chongseng yang berjudul Investment Management and Financial Innovation, mempertimbangkan efek hari libur dengan konteks budaya. Hari libur yang memiliki unsur kebudayaan lebih memiliki efek pada perekonomian dibandingkan dengan hari libur yang tidak memiliki unsur kebudayaan. Menurut Cadsby dan Ratner (1992) dan Yen dan Shyy (1993) hari libur yang memiliki unsur kebudayaan, seperti hari libur tahun baru China, memiliki pengaruh perekonomian yang besar pada banyak Negara Asia. Temuan mereka menunjukkan adanya "efek budaya", dalam hari libur, setidaknya di pasar saham dan pasar barang Asia. Di Indonesia, salah satu hari libur atau hari besar yang dapat mempangaruhi pertumbuhan ekonomi adalah bulan ramadhan dan idul fitri. Salah satu pemicu utamanya adalah kegiatan konsumsi ketika masyarakat melakukan mudik lebaran, sehingga perputaran vang pada daerah meningkat.

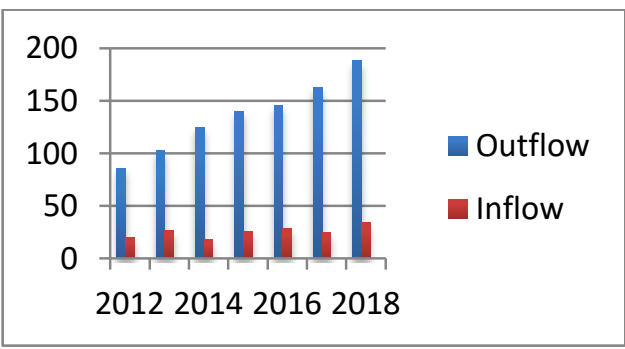

Sumber: Tabloid Kontan No. 37 edisi 11 Juni-17 Juni 2018

Gambar 1.
Perkembangan Kebutuhan Uang (Oufflow) dan Uang Kembali (Inflow) Periode Ramadhan dan Idul Fitri

Keterangan dari charts perputaran vang tersebut adalah royeksi Sebesar Rp 188 triliun selama 16 Mei-8 Juni 2018 (Hari pertama sampai dengan hari kerja terakhir di bulan Ramadhan), walaupun proyeksi awal hanya Rp 175 triliun. Perputaran vang tersebut tentu akan mendongkrak perekonomian di daerah, walaupun menurut Moh Faisal, direktur eksekutif core Indonesia, walaupun hari libur lebaran dan tradisi mudiknya dapat meningkatkan perputaran ekonomi daerah, hal tersebut hanya bersifat konsumtif dan mendatangkan mafaat sesaat untuk perekonomian setempat. Perputaran vang yang terjadi di masyarakat dapat menjadikan jumlah vang beredar meningkat, sehingga akan menyebabkan inflasi. Dalam jurnal Lubis Fahmi, menuliskan bahwa Ahluwaliyah (2014) mengatakan inflasi yang terjadi seharusnya dapat dikendalikan atau dikontrol sehingga tingkat inflasi tersebut dapat memberikan dampak positif terhadap pertumbuhan ekonomi.Sementara itu, kenaikan jumlah konsumsi rumah tangga pada triwulan dengan momen lebaran juga terlihat. 


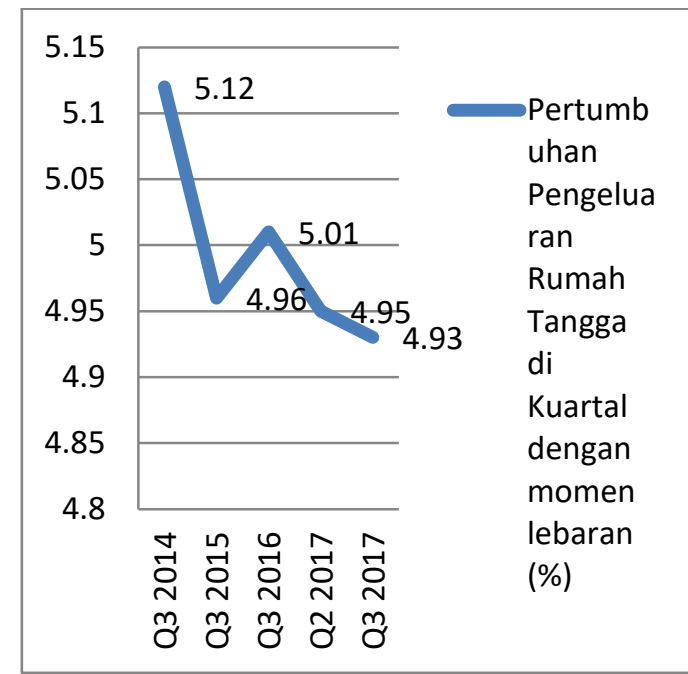

Sumber: Tabloid Kontan No. 37 edisi 11 Juni-17 Juni 2018

Gambar 2.

Pertumbuhan Pengeluaran Rumah Tangga di Triwulan dengan Momen Lebaran (\%)

Dengan adanya data di atas yang menunjukkan bahwa pengeluaran rumah tangga masyarakat mengalami pertumbuhan pada kuartal dengan momen ramadhan serta lebaran, seperti pada kuartal ke 2 tahun 2017 lebih tinggi 0,02 persen yaitu 4.95 persen di bandingkan dengan kuartal ke 3 tahun 2017 yang mencapai 4.93 persen. Walaupun kontribusi masyarakat terhadap total konsumsi rumah tangga secara nasional tidak besar, tapi ini tetap membantu laju pertumbuhan ekonomi dalam suatu Negara. Menurut website ekonomi kompas tanggal 5 Februari 2018 dengan artikel "berjudul konsumsi rumah tangga sumbang separuh struktur ekonomi" yang saya unduh pada tanggal 2 Januari 2019 menuliskan bahwa dari data BPS menyebutkan komponen konsumsi rumah tangga merupakan sumber utama pertumbuhan ekonomi
Indonesia tahun 2017, yakni sebesar 2,69 persen. Kemudian diikuti oleh komponen PMTB atau investasi sebesar 1.98 persen. Produk domestik bruto menurut pengeluaran didomnasi oleh komponen pengeluaran konsumsi rumah tangga sebesar 56,13 persen, diikuti oleh komponen PMTB atau investasi sebesar 32,16 persen dan komponen ekspor barang dan jasa sebesar 20,37 persen. Dapat disimpulkan perekonomian Indonesia ditopang oleh konsumsi rumah tangga, investasi dan ekspor. Perubahan tingkat pertumbuhan ekonomi ini tentu saja juga mendapatkan kontribusi dari event bulan Ramadhan serta idul fitri yang dirayakan oleh mayoritas masyarakat muslim di Indonesia, karena kuartal dengan Ramadhan memiliki produk domestik bruto tertinggi dibandingkan dengan kuartal diluar Ramadhan.

Berdasarkan latar belakang yang telah dikemukakan, maka peneliti bermaksud menganalisis mengenai pengaruh event bulan ramadhan dan idul fitri terhadap pertumbuhan ekonomi di Indonesia dengan melihat product domestic bruto Negara Indonesia periode 10 tahun terakhir yang di mulai dari tahun 2008 hingga tahun 2018 kuartal satu hingga tiga. Kajian ini selanjutnya akan diwujudkan dalam bentuk penelitian skripsi dengan judul, "Perbandingan kinerja pertumbuhan ekonomi pada kuartal Ramadhan dan Idul Fitri dengan kuartal selain Ramadhan dan Idul Fitri di Indonesia" dengan menggunakan 
Sribanu, et al/Jurnal Ekonomi Syariah Teori dan Terapan Vol. 6 No. 5 Mei 2019: 1007-1029; PERBEDAAN KINERJA PERTUMBUHAN EKONOMI PADA KUARTAL RAMADHAN DAN RATA-RATA KUARTAL DILUAR RAMADHAN DAN IDUL FITRI

periode selama 11 tahun yaitu 2008 hingga tahun 2018.

\section{LANDASAN TEORI}

\section{Ramadhan dan Hari Raya Idul Fitri}

Ramadhan adalah salah satu bulan dalam kalender hijriyah dan merupakan bulan yang suci bagi orang yang beragama Islam, karena pada bulan tersebut orang muslim percaya bahwa Ramadhan membawa berlimpah keberkahan. Pada bulan Ramadhan, orang beragama Islam diwajibkan untuk berpuasa menahan hawa nafsu selama satu bulan lamanya. Karena bagi orang Islam, berpuasa Ramadhan termasuk dalam salah satu rukun Islam. Setelah berhasil melakukan puasa dan menahan hawa nafsu selama kurang lebih satu bulan lamanya, maka umat muslim mengakhiri puasa Ramadhan mereka dengan merayakan hari raya Idul Fitri. Secara harafiyah, Idul Fitri artinya kembali ke fitrah, yakni menjadi sosok baru yang bersih layaknya bayi baru lahir.

Fenomena perayaan hari raya Idul Fitri berbeda-beda pada setiap negara, sesuai dengan adat istiadat, norma dan budaya yang dianut. Di Indonesia, fenomena yang sering terlihat ketika Idul Fitri adalah mudik dan berkunjung merekatkan silaturahmi kepada tetangga dan saudara. Perputaran vang yang terjadi ketika fenomena mudik, mendongkrak perekonomian di daerah walaupun bersifat sementara. Konsumsi masyarakat meningkat, karena budaya ketika hari raya Idul Fitri sering kali masyarakat mengingankan sesuatu yang baru untuk dikenakan ketika hari raya. Selain sebagai ajang silaturahmi dan merayakan kemenangan dalam menahan hawa nafsu selama sebulan, Idul Fitri memiliki dampak pada perputaran uang dan konsumsi walaupun bersifat sementara.

\section{Pertumbuhan Ekonomi}

Soekirno (2008) mengungkapkan bahwa pertumbuhan ekonomi merupakan perkembangan kegiatan dalam perekonomian yang menyebabkan barang dan jasa yang diproduksi di masyarakat bertambah, sehingga akan meningkatkan kesejahteraan masyarakat.Adam Smith dalam bukunya "The Law of Diminishing of Return", pertumbuhan ekonomi akan dipengaruhi oleh pertumbuhan produk domestik bruto (PDB) dan pertumbuhan jumlah penduduk. Pertumbuhan PDB dipengaruhi oleh beberapa faktor seperti sumber daya alam, jumlah penduduk dan persediaan modal. Sistem persaingan bebas juga termasuk faktor yang mempengaruhi, agar pertumbuhan ekonomi dapat meningkat. Sistem persaingan bebas dapat memberi kesempatan kepada individu untuk berkembang dan memilih kegiatan ekonomi sesuai dengan kehendaknya sehingga dapat mencapai target optimal yang diinginkan tanpa campur tangan dari pemerintah. Hal ini, dapat meningkatkan pertumbuhan ekonomi masyarakat. Pertumbuhan ekonomi 
Sribanu, et al/Jurnal Ekonomi Syariah Teori dan Terapan Vol. 6 No. 5 Mei 2019: 1007-1029; PERBEDAAN KINERJA PERTUMBUHAN EKONOMI PADA KUARTAL RAMADHAN DAN RATA-RATA KUARTAL DILUAR RAMADHAN DAN IDUL FITRI

memiliki faktor-faktor penting yang dapat dimanfaatkan agar negara dapat bergerak maju, yaitu faktor sumber daya alam, sumber daya manusia, teknologi, budaya dan modal.

\section{Pendapatan Nasional}

a. Sejarah Pendapatan Nasional

Di dalam jurnal milik Scarnicci, Manuela (2013) menuliskan konsep pendapatan nasional pertama kali dicetuskan di Inggris pada abad ke 17 oleh Sir William Petty, pertama kali upaya penghitungan kekayaan agregrat dilakukan dengan cara menghitung perkiraan populasi dan pendapatan nasional dalam tulisannya yang berjudul Political Arithmetic and Political Survey pada tahun 1672 (Scarnicci, 2013). Menurut ensiklopedia Britanica, dia termasuk salah satu penulis yang memahami kepentingan dari aspek kuantitif dalam ekonomi untuk memahami realita yang ada. Dalam perhitungannya, ia menggunakan anggapan bahwa pendapatan nasional merupakan penjumlah dari biaya hidup atau konsumsi selama satu tahun. Namun, pendapat tersebut tidak disepakati para ahli ekonomi modern, karena menurut pandangan ilmu ekonomi modern, konsumsi bukan satu-satunya unsur dalam perhitungan pendapatan nasional. Salah satu pengikut petty adalah Gregory King, ahli ekonomi Inggris yang menjadi salah satu bapak ekonometriks dan perhitungan pendapatan nasional. Dia terkenal sebagai "Raja hukum" di permintaan tidak elastis. Ketertarikan King akan perhitngan nasional bukan sebuah kebetulan, karena King adalah seorang ekonom yang bertanggung jawab atas kantor komisaris kerajaan di Inggris. Salah satu hal yang menjadi alasan pertama dalam penemuan perhitungan pendapatan nasional adalah terkait dengan perpajakan. King mempelajari tentang teori Petty dan sepuluh tahun kemudian mampu menciptakan gambaran tentang pendapatan nasional Inggris. Inovasi perhitungan baru ini mengestimasi populasi, kekayaan dan produk populer. King menyertakan produk popular diperhitungannya karena pajak yang dikeluarkan juga tinggi, karena sumber yang mereka peroleh adalah fiskal maka harus diperhitungkan (Toniolo 2008).

Perhitungan pendapatan nasional mulai berubah kembali secara signifikan dengan munculnya physiocracy, sebuah teori ekonomi yang menganggap bahwa pertanian sebagai satu-satunya kegiatan produktif yang mampu menciptakan nilai surplus atau yang dikenal sebagai net produk, yang tersisa setelah mengurangi biaya produksi. Pemikiran ini, berasal dari Francois Quesnay yang menulis buku "Tableau économique" (1758). Kontribusi Quesnay relevan dan berkat teorinya, konsep ketergantungan ekonomi mulai berkembang. Keterbatasan dari teori ini yaitu pertanian adalah satu-satunya kegiatan produktif. Hal inilah yang menjadikan mengapa pencatatan 
pendapatan nasional dalam sejarah selalu mengalami pembaruan.

Pendapatan nasional dapat diartikan sebagai jumlah barang dan jasa yang dihasilkan suatu negara pada periode, biasanya selama waktu satu tahun. Istilah yang terkait dengan pendapat nasional beragam, antara lain adalah produk domestic bruto, produk nasional bruto, serta produk nasional neto.Pendapatan nasional merupakan ukuran terhadap aliran uang dalam barang pada perekonomian yang dapat dihitung menggunakan tiga pendeketan, yaitu pendeketan produksi, pendekatan pendapatan dan pendekatan pengeluaran.

b. Pendapatan Nasional dalam Prespektif Islam

Nurul Huda (2008:27) menuliskan bahwa pendekatan ekonomi konvensional menyatakan produk domestic bruto (PDB) atau produk nasional bruto (PNB) riil dapat dijadikan sebagai suatu ukuran kesejahteraan ekonomi (measure of economic welfare) atau kesajahteraan pada suatu negara. Pada waktu PNB naik, maka diasumsikan bahwa rakyat secara materi bertambah baik posisinya atau sebaliknya, tentunya setelah dibagi dengan jumlah penduduk (PNB perkapita). Kritik terhadap PNB sebagai ukuran kesejahteraan ekonomi muncul dan para oengkritik mengatakan bahwa PNB perkapita merupakan ukuran kesejahteraan yang tidak sempurna.
Di dalam bukunya, Nurul Huda (2008) menuliskan, satu hal yang membedakan sistem ekonomi Islam dan sistem ekonomi lainnya adalah penggunaan parameter falah. Falah adalah kesejahteraan yang hakiki, kesejahteraan sebenarnya, dimana komponen rohaniah masuk dalam pengertian falah ini. Ekonomi islam dalam arti sebuah system ekonomi (nidhom aliqtishad) merupakan sebuah sistem yang dapat mengantar umat manusia pada real welfare (falah), kesejahteraan yang sebenarnya. Memang benar bahwa sistem ekonomi pada dasarnya bertujuan untuk mencapai kesejahteraan masyarakatnya, sehingga daya hidup terpenuhi. Apabila hanya bertujuan untuk memaksimalkan pendapatan perkapita, tanpa distribusi yang adil, maka kapitalis modern akan mendapatkan angka maksimal. Pendapatan perkapita yang tinggi bukan komponen pokok yang menyusun kesejahteraan, hal itu cukup mendorong dalam isu kesejahteraan dan namun bukan sesuatu yang terpenting dalam hal kesejahteraan. Karena tujuan utama dari sistem ekonomi islam adalah falah, maka selain tuntutan kebutuhan fisik, manusia harus memenuhi kebutuhan ruhani.

\section{Konsumsi}

Pengeluaran konsumsi rumah tangga merupakan salah satu variabel makro ekonomi dalam pembentukan produk domestik bruto dengan menggunakan pendekatan pengeluaran, 
Sribanu, et al/Jurnal Ekonomi Syariah Teori dan Terapan Vol. 6 No. 5 Mei 2019: 1007-1029; PERBEDAAN KINERJA PERTUMBUHAN EKONOMI PADA KUARTAL RAMADHAN DAN RATA-RATA KUARTAL DILUAR RAMADHAN DAN IDUL FITRI

variabel ini dilambangkan dengan huruf $C$ (Consumption). Apabila total pengeluaran konsumsi masyarakat dalam satu negara dijumlahkan, maka hasilnya adalah pengeluaran konsumsi rumah tangga negara yang bersangkutan.

Secara agregrat dalam jurnal Hanantijo yang berjudul "konsumsi nasional sebagai penggerak laju pertumbuhan ekonomi", pengeluaran konsumsi masyarakat berbanding lurus dengan pendapatan nasional. Semakin besar pendapatan, maka semakin besar pengeluaran konsumsi. Perbandingan besarnya tambahan pengeluaran konsumsi terhadap pendapatan disebut hasrat marjinal untuk berkonsumsi (Marginal Propensity to Consume/MPC). Seperti teori Keynes yang ditulis pada (Mankiw: 2006), masyarakat yang kehidupan ekonominya relatif sederhana biasanya angka MPC mereka relatif besar, sedangkan angka MPS mereka lebih kecil, artinya jika memperoleh tambahan pendapatan maka sebagian besar tambahan pendapatan tersebut akan teralokasi untuk melakukan konsumsi. Hal ini, berbanding terbalik dengan masyarakat yang memiliki ekonomi lebih mapan.

Menurut Rahardja (2001: 45) dalam jurnal Hanantijo, pengeluaran konsumsi terdiri atas pengeluaran konsumsi pemerintah (government consumption) dan konsumsi rumah tangga (household consumption). Beberapa alasan yang mendasari tingkat konsumsi rumah tangga yang pertama adalah pengeluaran konsumsi rumah tangga memiliki posisi terbesar dalam total pengeluaran agregrat. Kedua, konsumsi rumah tangga bersifat endogenous dalam arti besarnya konsumsi rumah tangga berkaitan dengan faktor lain yang mempengaruhinya. Ketiga, perkembangan masyarakat yang begitu cepat mengakibatkan perilaku konsumsi juga berubah cepat. Hal ini merupakan alasan lain untuk melakukan studi tentang konsumsi rumah tangga tetap relevan.

\section{Konsumsi dalam prespektif Islam}

Dalam ekonomi Islam, konsep konsumsi berbeda dengan konvensional. Karena pada konsumsi Islam, konsumen harus mengutamakan kebutuhan sebelum keinginan terpenuhi. Hal ini dilakukan agar konsumen tidak terjebak dalam lingkaran konsumerisme, karena manusia dianjurkan untuk tidak memaksakan keinginan mereka dan menghamburkan vang.

Imam Ghazali telah membedakan antara keinginan (raghbah dan syahwat) dan kebutuhan (hajah), kebutuhan adalah keinginan manusia untuk mendapatkan sesuatu yang diperlukannya dalam rangka mempertahankan kelangsungan hidupnya dalam menjalankan fungsinya. Selain itu, Imam Ghazali mementingkan niat dalam melakukan konsumsi, sebab konsumsi dilakukan dalam rangka mendekatakan diri dan mencari ridha Allah SWT (Fauzia dan Riyadi: 2006). 
Sribanu, et al/Jurnal Ekonomi Syariah Teori dan Terapan Vol. 6 No. 5 Mei 2019: 1007-1029; PERBEDAAN KINERJA PERTUMBUHAN EKONOMI PADA KUARTAL RAMADHAN DAN RATA-RATA KUARTAL DILUAR RAMADHAN DAN IDUL FITRI

Menurut jurnal "The framework for Islamic Theory of Consumer Behaviour" oleh M. Fahim Khan menuliskan bahwa beberapa ahli ekonom Islam klasik mendiskusikan tentang prioritas dan kategori dari kebutuhan, namun tidak secara spesifik meneliti tentang kebiasaan seorang konsumen. Ibnu Khaldun mengkategorikan bahwa konsumsi terbagi menjadi tiga, yaitu kebutuhan dasar atau primer (daruriyat), kebutuhan sekunder (hajiyat atau ta'miliyat) dan kebutuhan tersier atau kebutuhan mewah (tahsiniyat). Selain itu, Fahim Khan juga menuliskan bahwa terdapat aturan dan norma dalam melakukan konsumsi, yaitu mengkonsumsi untuk keindahan, mengkonsumsi sesuatu yang baik dan tidak membahayakan, tidak boleh berbuat semena-mena terhadap kekuasaan atau kekayaan yang dimiliki, sehingga apapun yang diinginkan harus terpenuhi. Konsumsi dianjurkan untuk menghindari kerusakan sumber daya yang ada, tidak boleh korupsi terhadap hasil bumi, Allah berfirman pada surat $\mathrm{Ar}$ Rum ayat 41 :

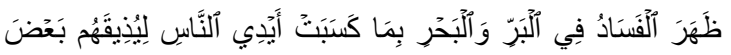

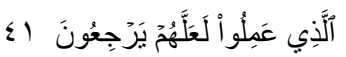

zhoharol-fasaadu fil-barri wal-bahri bimaa kasabat aidin-naasi liyuziiqohum ba'dhollazii 'amiluu la'allahum yarji'uun

Artinya:

"Telah nampak kerusakan di darat dan di laut disebabkan karena perbuatan tangan manusi, supay Allah merasakan kepada mereka sebahagian dari (akibat) perbuatan mereka, agar mereka kembali (ke jalan yang benar)."

Dalam jurnal "The framework for Islamic Theory of Consumer Behaviour" oleh M. Fahim Khan menuliskan konsumsi didalam islam juga sebagai alat untuk membantu sesama, dengan menyisihkan harta yang dimiliki untuk orang lain. Seperti yang ada di Al Quran surat Al Baqarah ayat 261:

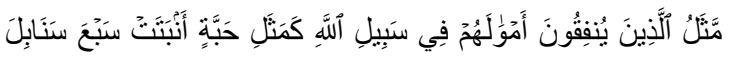

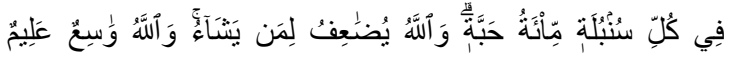

masalullaziina yunfiquuna amwaalahum fii sabiilillaahi kamasali habbatin ambatat sab'a sanaabila fii kulli sumbulatim mi atu habbah, wallohu yudhoo'ifu limay yasyaaa', wallohu waasi'un 'aliim

Artinya: "Perumpamaan (nafkah yang dikeluarkan oleh) orang-orang yang menafkahkan hartanya di jalan Allah adalah serupa dengan sebutir benih yang menumbuhkan tujuh bulir, pada tiap-tiap bulir seratus biji. Allah melipat gandakan (ganjaran) bagi siapa yang Dia kehendaki. Dan Allah Maha Luas (karuniaNya) lagi Maha Mengetahui".

Penyisihan harta yang dimiliki untuk membantu orang lain di Islam ada bermacam-macam, yaitu sadaqah, qard al hasan, infaq, zakat dan wakaf

\section{Konsumsi Terhadap Pertumbuhan Ekonomi}

Konsumsi adalah salah satu variabel penentu pertumbuhan ekonomi, terlebih lagi di Indonesia pengeluaran konsumsi rumah tangga sangat memiliki peran terhadap produk domestik bruto. Menurut jurnal milik Hanantijo yang 
Sribanu, et al/Jurnal Ekonomi Syariah Teori dan Terapan Vol. 6 No. 5 Mei 2019: 1007-1029; PERBEDAAN KINERJA PERTUMBUHAN EKONOMI PADA KUARTAL RAMADHAN DAN RATA-RATA KUARTAL DILUAR RAMADHAN DAN IDUL FITRI

berjudul "konsumsi nasional sebagai penggerak laju pertumbuhan ekonomi", sebagai indicator kesejahteraan, tingkat konsumsi akan menentukan kualitas pembangunan manusia Indonesia yang terekam dalam Indeks Pembangunan Manusia (IPM). Pemahaman terhadap konsumsi penduduk Indonesia selain berguna untuk memahami kondisi kesejahteraan penduduk Indonesia, juga untuk mempercepat pencapaian MDGs atau Millinium Development Goals yang telah direncanakan oleh pemerintah. Hal ini terjadi karena bila konsumsi meningkat, maka pendapatan masyarakat juga meningkat yang mendakan kesejahteraan, masyarakat mampu memenuhi barang kebutuhannya. Ketika kenaikan belanja pemerintah meningkatkan pendapatan, maka akan meningkatkan konsumsi, yang selanjutnya akan terus berputar seperti itu.

Pengeluaran konsumsi rumah tangga merupakan nilai belanja yang dilakukan oleh rumah tangga untuk membeli berbagai jenis kebutuhannya dalam periode tertentu. Pendapatan yang diterima oleh rumah tangga akan digunakan untuk membeli makanan, pakaian, biaya jasa pengangkutan, membayar pendidikan, membayar sewa dan membeli kendaraan. Barang-barang tersebut dibeli rumah tangga untuk memenuhi kebutuhannya (Sukirno, 1994). Keputusan konsumsi rumah tangga dipengaruhi keseluruhan prilaku jangka panjang maupun jangka pendek.
Keputusan konsumsi rumah tangga jangka panjang adalah penting karena peranannya dalam pertumbuhan ekonomi, sedangkan jangka pendek penting dalam menentukan permintaan agregrat.

Konsumsi di dalam PDB sangat penting, terlebih lagi pada produk domestik bruto Indonesia, dikarenakan menurut website ekonomi kompas tanggal 5 Februari 2018 dengan artikel "berjudul konsumsi rumah tangga sumbang separuh struktur ekonomi" yang diunduh pada tanggal 2 Januari 2019 menuliskan bahwa dari data BPS menyebutkan komponen konsumsi rumah tangga merupakan sumber utama pertumbuhan ekonomi Indonesia tahun 2017, yakni sebesar 2,69 persen. Kemudian diikuti oleh komponen PMTB atau investasi sebesar 1.98 persen. Produk domestik bruto menurut pengeluaran didomnasi oleh komponen pengeluaran konsumsi rumah tangga sebesar 56,13 persen, diikuti oleh komponen PMTB atau investasi sebesar 32,16 persen dan komponen ekspor barang dan jasa sebesar 20,37 persen. Dapat disimpulkan perekonomian Indonesia ditopang oleh konsumsi rumah tangga, investasi dan ekspor. Konsumsi dapat dikatakan nilainya adalah dua per tiga dari PDB.

Dalam The General Theory milik Keynes mengatakan bahwa pendapatan total perekeonomian dalam jangka pendek, sangat ditentukan oleh keinginan rumah tangga, perusahaan dan 
Sribanu, et al/Jurnal Ekonomi Syariah Teori dan Terapan Vol. 6 No. 5 Mei 2019: 1007-1029; PERBEDAAN KINERJA PERTUMBUHAN EKONOMI PADA KUARTAL RAMADHAN DAN RATA-RATA KUARTAL DILUAR RAMADHAN DAN IDUL FITRI

pemerintah untuk membelanjakan pendapatannya. Semakin banyak orang yang mengeluarkan pendapatannya, semakin banyak barang dan jasa yang bisa dijual oleh perusahaan. Semakin banyak perusahaan yang menjual, semakin banyak output yang akan diproduksi dan semakin banyak pekerja yang akan dikaryakan (Mankiw, 2006:274).

\section{METODE PENELITIAN}

\section{Pendekatan Penelitian}

Pendekatan yang digunakan dalam penelitian ini adalah pendekatan kuantitatif.Pendekatan kuantitatif merupakan pendekatan yang menitikberatkan pada pembuktian hipotesis, dan melakukannya melalui berbagai pengujian. Menurut Sugiyono (2018:15) metode kuantitatif dapat diartikan sebagai metode penelitian yang berlandaskan pada filsafat positivisme, digunakan untuk meneliti pada populasi atau sample tertentu, pengumpulan data menggunakan instrumen penelitian, analisis data bersifat kuantitatif atau statistik, dengan tujuan untuk menggambarkan dan menguji hipotesis yang telah di tetapkan. Menurut Syofian Siregar (2012:30) tujuan akhir penelitian kuantitatif adalah menguji teori, membangun fakta, menunjukkan hubungan dan pengaruh serta perbandingan antar variabel, memberikan deskripsi secara statistik, menafsirkan dan meramalkan hasil akhirnya.

\section{Identifikasi Variabel}

Menurut Sugiyono (2018:55) kata variabel hanya ada pada pnelitian kuantitaif, karena penelitian kuantitatif berpandangan bahwa suatu gejala dapat diklasifikasikan menjadi variabelvariabel. Secara teoritis variabel dapat didefinisikan sebagai atribut seeorang atau objek yang memunyai variasi antara saru orang dengan yang lain atau satu objek dengan objek yang lain (Hatch dan Farhady: 1981). Menurut Cresswell, 2012 pada buku milik Sugiyono (2018:56), Variabel adalah karakteristik atau atribut dari individu atau organisasi yang dapat diukur atau diobservasi yang bisa bervariasi antara orang dan organisasi yang diteliti. Variabel dapat diteliti sehingga menghasilkan data yang bersifat kategori (data diskrit atau nominal) atau data kontinum (ordinal, interval dan ratio). Variabel yang digunakan dalam penelitian ini hanyalah variabel penelitian.

\section{Definisi Operasional Variabel}

Pertumbuhan ekonomi menurut badan pusat statistik adalah pertumbuhan produksi barang dan jasa di suatu wilayah perekonomian dalam periode waktu tertentu. Data pada pertumbuhan ekonomi menggunakan satuan persen (\%). Bentuk data bersifat triwulan atau kuartal, karena menurut kbbi kuartal adalah suku tahun (waktu seperempat tahun, yaitu tiga bulan).

Berdasarkan penelitian yang berjudul "perbandingan kinerja 
Sribanu, et al/Jurnal Ekonomi Syariah Teori dan Terapan Vol. 6 No. 5 Mei 2019: 1007-1029; PERBEDAAN KINERJA PERTUMBUHAN EKONOMI PADA KUARTAL RAMADHAN DAN RATA-RATA KUARTAL DILUAR RAMADHAN DAN IDUL FITRI

pertumbuhan ekonomi pada kuartal Ramadhan dan Idul Fitri dengan kuartal selain Ramadhan dan Idul Fitri di Indonesia" ini, maka variabel penelitiannya adalah pertumbuhan ekonomi di Indonesia mulai tahun 2008 hingga 2018.

\section{Penentuan Populasi dan Sampel}

Sugiyono (2018:130) populasi adalah keseluruhan element yang akan dijadikan wilayah generalisasi. Elemen populasi adalah keseluruhan subjek yang akan diukur, yang merupakan unit yang diteliti. Secara umum, populasi penelitian adalah keseluruhan objek penelitian yang dapat berupa objek manusia, hewan, tumbuh-tumbuhan, udara, gejala, nilai, peristiwa, sikap hidup, dan sebagainya. Semua objek tersebut dapat menjadi sumber data penelitian (Bungin, 2006:99).

$$
\text { Menurut Sugiyono (2018:131) }
$$

dalam penelitian kuantitatif, sampel adalah bagian dari jumlah dan karakteristik yang dimiliki oleh populasi tersebut. Bila populasi besar dan peneliti tidak mungkin mempelajari semua yang ada pada populasi, maka peneliti dapat menggunakan sampel yang diambil dari populasi itu. Apa yang dipelajari dari sampel itu, kesimpulannya akan dapat diberlakukan untuk populasi. Sampel yang diambil dari populasi harus betul-betul representatif atau mewakili. Teknik sampling pada dasarnya daat dikelompokkan menjadi dua, yaitu probability sampling dan nonprobability sampling.
Nonprobability sampling adalah teknik yang tidak memberi peluang atau kesempatan yang sama bagi setiap unsur atau anggota populasi untuk dipilih menjadi sampel, dalam penelitian ini teknik sampel yang digunakan adalah sampling jenuh. Sampling jenuh merupakan teknik penentuan sampel bila semua anggota populasi digunakan sebagai sampel. Istilah lain sampling jenuh adalah sensus, dimana semua anggota populasi dijadikan sampel (Anshori dan Iswati, 2014:106). Pada penelitian ini teknik penarikan sampel dan populasi yang digunakan adalah pertumbuhan ekonomi di indonesia selama tahun 2008 hingga tahun 2018 dengan menggunakan kuartal dan satuan bersifat persen (\%).

\section{Jenis dan Sumber Data}

Sugiyono (2018:213) menuliskan bahwa pengumpulan data dapat dilakukan dalam berbagai setting, berbagai sumber dan berbagai cara. Bila dilihat dari sumber datanya, maka pengumpulan data dapat menggunakan sumber primer dan sumber sekunder.

Data Sekunder adalah data yang telah lebih dahulu dikumpulkan dan dilaporkan oleh orang atau instansi di luar peneliti sendiri (Moh. Pabundu, 2006:58). Sugiyono (2018:213) menuliskan bahwa sumber data sekunder adalah data yang tidak langsung memberikan data kepada pengumpul data, misalnya adalah melalui orang lain atau dokumen.

Pada penelitian ini, data yang digunakan adalah data sekunder karena 
Sribanu, et al/Jurnal Ekonomi Syariah Teori dan Terapan Vol. 6 No. 5 Mei 2019: 1007-1029; PERBEDAAN KINERJA PERTUMBUHAN EKONOMI PADA KUARTAL RAMADHAN DAN RATA-RATA KUARTAL DILUAR RAMADHAN DAN IDUL FITRI

sumber data diperoleh berasal dari website badan pusat statistik serta literature berupa dokumen, jurnal dan buku panduan.

\section{Metode Pengumpulan Data}

Pengumpulan data yang diperlukan diperoleh melalui online, data dengan judul dokumen bps-file.xls yang terdiri dari file produk domestik bruto tahun 2008 hingga tahun 2018 diunduh dari website institusi badan pusat statistik dan bank Indonesia secara online. Dan studi kepustakaan dilakukan dengan mengumpulkan data, mempelajari sera mengutip teori dari buku dan jurnal ekonomi yang berhubungan dengan permasalahan dari penelitian ini.

\section{Metode Analisis Data}

Tahap pertama untuk membuktikan bahwa event ramadhan serta idul fitri memiliki pengaruh terhadap pertumbuan ekonomi Indonesia, maka akan dilakukan analisis berdasarkan teoriteori yang mendukung penelitian. Pertama, mengidentifikasi event ramadhan yang akan dijadikan sebagai penelitian, periode pengamatan yang akan dilakukan pada penelitian ini yaitu selama 11 tahun dimana masing-masing tahun mengambil kuartal yang terdapat Ramadhan serta kuartal di luar Ramadhan. Menggunakan kuartal karena menurut kamus besar bahasa Indonesia, kuartal berarti suku tahun (waktu seperempat tahun; yaitu waktu tiga bulan); triwulan; waktu satu tahun dibagi empat. Data yang digunakan sebagai penelitian yaitu 11 kali kuartal yang terdapat bulan Ramadhan dan 11 kuartal di luar Ramadhan, hal ini dikarenakan terdapat 3 kuartal di luar Ramadhan, namun di rata-rata sehingga perbandingan datanya sama. Software yang digunakan untuk mengolah data adalah software stata versi 14 .

1. Uji Normalitas

Uji normalitas bertujuan untuk mengetahui apakah data penelitian terdistribusi secara normal atau tidak. Uji normalitas data dapat dilakukan dengan beberapa uji statistik, yaitu uji Shapiro-Wilk, uji Skweness dan Kurtosis, uji KolmogorovSmirnow dan uji Liliefors. Pada penelitian ini, saya akana menggunakan uji normalitas Shapiro-Wilk. Dasar pengambilan keputusan dalam uji normalitas Shapiro-Wilk, yaitu:

a. Jika nilai Sig. > 0,05 maka data berdistribusi secara normal

b. Jika nilai sig. $<0,05$ maka data tidak berdistribusi normal

2. Uji T-test

T-test pertama kali dikembangkan oleh William S. Gosset pada tahun 1908. Gosset awalnya mengembangkan t-test sebagai akibat dari kesulitan untuk melakukan penelitian eksperimen. Namun, temuannya ini tidak langsung dipublikasikan, hingga pada saat memperkenalkan $\dagger$ distribution sering disebut student's t. T-test digunakan pada situasi ketika sampel yang digunakan adalah kecil dan variabilitas dari besarnya populasi tidak diketahui. T-test terbagi 
Sribanu, et al/Jurnal Ekonomi Syariah Teori dan Terapan Vol. 6 No. 5 Mei 2019: 1007-1029; PERBEDAAN KINERJA PERTUMBUHAN EKONOMI PADA KUARTAL RAMADHAN DAN RATA-RATA KUARTAL DILUAR RAMADHAN DAN IDUL FITRI

menjadi one sample t-test, independent $\dagger-$ test dan dependent t-test (Latan: 2014).

Dependent t-test atau paired sampel t-test digunakan untuk mengetahui apakah terdapat perbedaan rata-rata dua sampel yang berpasangan atau berhubunan. Jika nilai probabilitas atau Sig. <0,05, maka terdapat perbedaan signifikan. Sebaliknya, jika nilai probabilitas atau Sig. > 0,05 maka tidak terdapat perbedaan yang signifikan.

Sebelum melakukan uji t-test, perlu diketahui bahwa diperlukan melakukan uji normalitas terlebih dahulu. Selain itu, data yang diuji adalah data kuantitatif (data interval atau data rasio).

\section{HASIL PENELITIAN}

Penelitian ini dilakukan dengan tujuan untuk mengetahui perbedaan kinerja pertumbuhan ekonomi pada kuartal Ramadhan dan Idul Fitri dengan kuartal diluar Ramadhan dan Idul Fitri. Data yang diambil adalah sumber data sekunder, yang diunduh dari website resmi badan pusat statistik dan bank indonesia terkait dengan produk domestik bruto perkuartal.

\section{Analisis}

Ramadhan merupakan bulan suci bagi umat islam di seluruh dunia dan Idul Fitri merupakan salah satu hari raya penting yang dirayakan setelah Ramadhan. Hari raya Idul Fitri merupakan perayaan umat islam, sebagai bentuk keberhasilan mereka dalam menahan hawa nafsu berpuasa selama satu bulan penuh dan sebagai momen untuk bersilaturahmi kepada sesama terutama sanak saudara. Bulan Ramadhan dan hari raya Idul Fitri berdasarkan pada penanggalan kalender Islam atau Hijriyah, yang merupakan kalender bulan, bukan kalender Gregorian yang merupakan kalender matahari. Tahun Masehi didasarkan pada peredaran bumi mengitari matahari sehingga sangat berguna untuk kegiatan-kegiatan yang berbasis pada musim. Sementara kalender Hijriyah didasarkan pada peredaran bulan dalam mengitari bumi, perubahan tersebut dapat dilihat dari bentuk dan posisi bulan. Sebagaimana yang tertera dalam $\mathrm{Al}$ Quran surat Al Baqarah ayat 189 dan Hadits riwayat Al Bukhari:

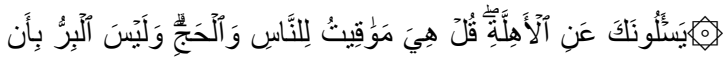

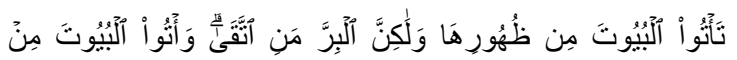

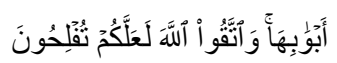
yas`aluunaka 'anil-ahillah, qul hiya mawaaqiitu lin-naasi wal-hajj, wa laisalbirru bi’an ta`tul-buyuuta min zhuhuurihaa wa laakinnal-birro manittagoo, wa`tulbuyuuta min abwaabihaa wattaqulloha la'allakum tuflihuun

Artinya: "Mereka bertanya kepadamu (wahai Muhammad) mengenai (peredaran) bulan, katakanlah: "Bulan sabit itu adalah tanda-tanda waktu bagi manusia dan bagi haji. Dan bukanlah perkara kebajikan: kamu memasuki rumah dari bahagian belakangnya (ketika kamu berihram) akan tetapi kebajikan itu ialah perbuatan orang yang bertaqwa; dan masuklah ke rumah (Kamu) itu melalui 
pintunya, serta bertaqwalah kamu kepada Allah supaya kamu berjaya" (QS. Al Baqarah: 189).

Dalam jurnal penentuan hari dalam sistem kalender hijriyah milik Ahmad Adib Rofiundin, Muhammad Jawab Mughniyah mengatakan bahwa seluruh kaum muslim sepakat apabila ada yang melihat hilal seorang diri, maka ia wajib mengamalkan apa yang dilihatnya tanpa membedakan hilal Ramadhan dengan hilal Syawal. Barangsiapa yang melihat hilal Ramadhan, maka ia wajib berpuasa, walaupun semua manusia tidak berpuasa. Barangsiapa yang melihat hilal Syawal, maka wajib berbuka walaupun semua orang di bumi masih dalam keadaan berpuasa. Tidak membedakan apakah yang melihat itu orang yang adil atau tidak, wanita atau laki-laki sekalipun. Sebagai orang yang mengaku Islam, puasa diwajibkan karena termasuk satu dari lima rukun islam yang ada.

Karena hal tersebut, maka bulan Ramadhan yang berdasarkan pada penanggalan Hijiyah selalu berbedabeda pada penanggalan kalender Masehi. Pada tabel di bawah ini, penulis akan menjabarkan produk domestik bruto pada kuartal satu hingga kuartal empat pada tahun 2008 hingga tahun 2010. Kuartal dan produk domestik bruto yang dibold, yaitu kuartal yang terdapat bulan Ramadhan. Sedangkan kuartal yang tidak dibold, yaitu kuartal diluar bulan Ramadhan.
Tabel 1.

Product Domestik Bruto 2008-2018

q-to-q

\begin{tabular}{|c|c|c|c|c|}
\hline NO & Tahun & $\begin{array}{l}\text { Tanggal } \\
\text { bulan } \\
\text { Ramadhan }\end{array}$ & Kuartal & GDP \\
\hline \multirow[t]{4}{*}{1} & 2008 & $\begin{array}{l}1 \\
\text { September } \\
2008\end{array}$ & 1 & 2.41 \\
\hline & & & 2 & 2.77 \\
\hline & & & 3 & 3.74 \\
\hline & & & 4 & $\begin{array}{c}- \\
3.57\end{array}$ \\
\hline \multirow[t]{4}{*}{2} & 2009 & $\begin{array}{l}8 \text { Agustus } \\
2009\end{array}$ & 1 & 1.67 \\
\hline & & & 2 & 2.39 \\
\hline & & & 3 & 3.88 \\
\hline & & & 4 & $\begin{array}{c}- \\
2.34 \\
\end{array}$ \\
\hline \multirow[t]{4}{*}{3} & 2010 & $\begin{array}{l}11 \text { Agustus } \\
2010\end{array}$ & 1 & 0.66 \\
\hline & & & 2 & 4.07 \\
\hline & & & 3 & 3.86 \\
\hline & & & 4 & 2.12 \\
\hline \multirow[t]{4}{*}{4} & 2011 & $\begin{array}{l}1 \text { Agustus } \\
2011\end{array}$ & 1 & 0.64 \\
\hline & & & 2 & 3.86 \\
\hline & & & 3 & 3.61 \\
\hline & & & 4 & 2.18 \\
\hline \multirow[t]{4}{*}{5} & 2012 & 21 juli 2012 & 1 & 0.8 \\
\hline & & & 2 & 3.96 \\
\hline & & & 3 & 3.35 \\
\hline & & & 4 & $\begin{array}{c}- \\
2.25 \\
\end{array}$ \\
\hline \multirow[t]{4}{*}{6} & 2013 & 10 Juli 2013 & 1 & 0.49 \\
\hline & & & 2 & 4 \\
\hline & & & 3 & 3.28 \\
\hline & & & 4 & 2.18 \\
\hline \multirow[t]{4}{*}{7} & 2014 & $\begin{array}{l}29 \text { Juni } \\
2014\end{array}$ & 1 & 0.04 \\
\hline & & & 2 & 3.83 \\
\hline & & & 3 & 3.27 \\
\hline & & & 4 & $\begin{array}{c}- \\
2.07 \\
\end{array}$ \\
\hline \multirow[t]{4}{*}{8} & 2015 & $\begin{array}{l}18 \text { Juni } \\
2015\end{array}$ & 1 & $\begin{array}{c}- \\
0.16\end{array}$ \\
\hline & & & 2 & 3.74 \\
\hline & & & 3 & 3.31 \\
\hline & & & 4 & $\begin{array}{c}- \\
1.73 \\
\end{array}$ \\
\hline 9 & 2016 & 6 Juni 2016 & 1 & - \\
\hline
\end{tabular}




\begin{tabular}{|c|c|c|c|c|}
\hline & & & & 0.36 \\
\hline & & & 2 & 4.01 \\
\hline & & & 3 & 3.14 \\
\hline & & & 4 & $\begin{array}{c}- \\
1.81\end{array}$ \\
\hline \multirow[t]{4}{*}{10} & 2017 & $\begin{array}{l}27 \text { Mei } \\
2017\end{array}$ & 1 & -0.3 \\
\hline & & & 2 & 4.01 \\
\hline & & & 3 & 3.19 \\
\hline & & & 4 & -1.7 \\
\hline \multirow[t]{3}{*}{11} & 2018 & $\begin{array}{l}17 \text { Mei } \\
2018\end{array}$ & 1 & $\begin{array}{c}- \\
0.41\end{array}$ \\
\hline & & & 2 & 4.21 \\
\hline & & & 3 & 3.09 \\
\hline
\end{tabular}

Sumber: BPS dan diolah oleh Penulis

Data diatas menunjukkan produk domestik bruto Indonesia sejak tahun 2008 hingga tahun 2018 yang menggunakan PDB pengeluaran. Karena bulan Ramadhan menggunakan penanggalan Hijriyah sedangkan Indonesia menggunalan penanggalan dengan sistem Masehi, maka data yang ada dikelola dengan cara menepatkan pada kuartal ke berapakah bulan Ramadhan setiap tahunnya terjadi.

Pada tahun 2008, bulan Ramadhan terjadi pada tanggal 1 September yang menjadikan Ramadhan jatuh pada kuartal ke 3 tahun 2008. Pada tahun 2009, bulan Ramadhan jatuh pada tanggal 8 Agustus yang berarti masih dalam kuartal ke 3. Pada tahun 2010, bulan Ramadhan jatuh pada tanggal 10 Agustus yang berarti masih dalam kuartal ke 3. Pada tahun 2011, bulan Ramadhan masih jatuh pada kuartal ketiga yaitu pada tanggal 1 Agustus 2018.

Pada tahun 2012 hingga tahun 2013, tanggal 1 Ramadhan jatuh pada bulan Juli dan nilai PDB dengan kuartal Ramadhan senilai $3,35 \%$ dan $3,28 \%$. Pada tahun 2014 dan 2015, tanggal 1 Ramadhan jatuh pada bulan Juni atau kuartal ke 2, namun dimasukkan dalam kuartal ke 3 karena mengambil hari Ramadhan terbanyak pada kedua kuartal tersebut antara kuartal kedua dan ketiga. Pada tahun 2016, bulan Ramadhan dimulai pada tanggal 6 Juni dan masuk pada kuartal kedua dengan nilai PDB kuartal senilai $4,01 \%$. Pada tahun 2017 dan 2018, bulan Ramadhan dimulai pada bulan Mei dan berada pada kuartal kedua dengan masing-masing perolehan PDB kuartal dengan Ramadhan senilai $4,01 \%$ dan $4,21 \%$.

\section{Statistik Deskriptif Produk Domestik Bruto}

Pada Subab bagian ini akan dijelaskan mengenai hasil pengolah data produk domestik bruto (PDB) Indonesia selama periode pengamatan yakni pada tahun 2008 hingga tahun 2018 di kuartal dengan Ramadhan dan kuartal diluar Ramadhan.

Statistik deskriptif memberikan gambaran umum dari variabel penelitian yaitu pertumbuhan ekonomi dari produk domestik bruto (PDB). Analisis yang digunakan adalah nilai rata-rata (mean), nilai minimum, nilai maksimum dan standar deviasi. Table berikut merupakan hasil statistic deskriptif dari produk domestik bruto pada tahun 2008 hingga tahun 2018 yang menjadi variabel penelitian selama periode pengamatan.

Tabel 2.

Hasil Statistik Deskriptif Kuartal Ramadhan dan Diluar Ramadhan

\begin{tabular}{l|l|l|l|l|l}
\hline Variabl & $\mathrm{O}$ & Mean & Std. & Min & M \\
\hline
\end{tabular}




\begin{tabular}{|l|r|r|r|r|r|}
\hline e & bs & & Dev. & & ax \\
\hline Ramad & & 3.6845 & 0.3395 & & 4.2 \\
han & 11 & 45 & 988 & 3.27 & 1 \\
\hline & & 0.6942 & 0.2757 & 0.32 & 1.3 \\
diluar & 11 & 418 & 988 & 333 & 4 \\
\hline
\end{tabular}

Sumber: Data diolah oleh penulis

Diketahui pada table pada periode ramadhan, nilai minimum pada produk domestik bruto kuartal dengan Ramadhan adalah 3,27 dan nilai maksimum sebesar 4,21. Nilai mean (ratarata) sebesar 3,684545 dengan standar deviasi sebesar 0,3395988. Nilai mean menunjukkan bahwa rata-rata tingkat produk domestic bruto Indonesia selama tahun 2008 hingga tahun 2018 pada kuartal dengan Ramadhan adalah 3,684545

Pada periode kuartal diluar Ramadhan, nilai minimum pada produk domestik bruto kuartal dengan diluar Ramadhan adalah 0,32333 dan nilai maksimum sebesar 1,34. Nilai mean (ratarata) sebesar 0,6942418 dengan standar deviasi sebesar 0,2757988. Nilai mean menujukkan bahwa rata-rata tingkat produk domestik bruto Indonesia selama tahun 2008 hingga tahun 2018 kuartal diluar Ramadhan adalah 0,6942418.

\section{Analisis Model dan Pengujian Hipotesis} Uji Normalitas

Sebelum memulai uji hipotesis, akan dilakukan uji normalitas data. Kegunaan dari pengujian normalitas data adalah untuk mengetahui apakah data yang ada telah terdistribusi secara normal. Jenis uji normalitas yang akan digunakan adalah uji Saphiro-Wilk normality test. Jika data terbukti terdistribusi normal, maka dapat dilanjutkan pengujian dengan menggunakan paired sample t-test. Jika data tidak terdistibusi secara normal, maka selanjutnya dapat dilakukan uji peringkat Wilcoxon (Wilcoxon Signed Rank Test). Apabila dalam perthitungan diperoleh nilai signifikan $\geq 0,05$ maka data tersebut berdistribusi normal. Sebaliknya, apabila nila signifikan $\leq 0,05$ maka data tidak berdistribusi normal. Data berikut merupakan hasil uji Saphiro-Wilk normality test pada produk domestik burto Indonesia mulai tahun 2008 hingga tahun 2018.

\section{Tabel 3.}

Hasil Uji Normalitas Produk Domestik Bruto Shapiro-Wilk $W$ test for normal data

\begin{tabular}{|l|r|l|l|l|l|}
\hline Variable & Obs & W & V & Z & Prob >z \\
\hline Ramadhan & 11 & 0.89805 & 1.651 & 0.935 & 0.17495 \\
\hline & & & & & \\
diluar & 11 & 0.91572 & 1.365 & 0.569 & 0.28461 \\
\hline
\end{tabular}

Sumber: Diolah oleh penulis

Dari hasil uji Shapiro-Wilk normality test diatas dapat diambil kesimpulan bahwa variabel produk domestik bruto atau pertumbuhan ekonomi berdistribusi secara normal, dengan probabilitas 0,17495 dan 0,28461 atau diatas tingkat signifikansi 0,05.

\section{Analisis dengan uji Paired Sample t-test}

Pengujian menggunakan uji paired sample t-test ini bertujuan untuk membuktikan adanya perbedaan pertumbuhan ekonomi melalu data produk domestik bruto Indonesia pada kuartal Ramadhan dan kuartal di luar Ramadhan. Berikut merupakan hasil 
perhitungan uji paired sample t-test pada produk domestik bruto Indonesia dari tahun 2008 hingga tahun 2010 menggunakan alat bantu stata ver.14.

Tabel 4.

Hasil Uji Produk Domestik Bruto Kuartal Ramadhan dan Diluar Ramadhan Paired t test

\begin{tabular}{|l|l|l|r|r|r|r|}
\hline $\begin{array}{l}\text { Vari } \\
\text { able }\end{array}$ & $\begin{array}{l}\text { O } \\
\mathbf{b} \\
\mathbf{s}\end{array}$ & $\begin{array}{l}\text { Mea } \\
\mathbf{n}\end{array}$ & $\begin{array}{l}\text { Std. } \\
\text { Err. }\end{array}$ & $\begin{array}{l}\text { Std. } \\
\text { Dev. }\end{array}$ & $\begin{array}{l}\text { [95\% } \\
\text { Conf } \\
\text {. }\end{array}$ & $\begin{array}{l}\text { Inter } \\
\text { val] }\end{array}$ \\
\hline Ram & & & 0.10 & 0.33 & & 3.91 \\
adh & 1 & 3.68 & 2392 & 9598 & 3.45 & 269 \\
an & 1 & 4545 & 9 & 8 & 64 & 1 \\
\hline \multirow{2}{*}{ dilu } & & 0.69 & 0.08 & 0.50 & 0.50 & 0.87 \\
ar & 1 & 4241 & 3156 & 8957 & 8957 & 952 \\
& 1 & 8 & 5 & 7 & 7 & 6 \\
\hline & & & 0.12 & & & 3.26 \\
diff & 1 & 2.99 & 4521 & 2.71 & 2.71 & 775 \\
& 1 & 0304 & 5 & 2852 & 2852 & 5 \\
\hline
\end{tabular}

Sumber: BPS dan diolah oleh penulis

mean (diff) $=$ mean (ramadhan - diluar $)$

$t=24.0143$

Ho: mean(diff) $=0$

degrees of freedom $=\quad 10$

Ha: mean (diff) $<0$

Ha: mean(diff) != 0

Ha: mean (diff) $>0$

$\operatorname{Pr}(T<t)=1.0000$

$\operatorname{Pr}(|T|>|\dagger|)=0.0000$

$\operatorname{Pr}(\mathrm{T}>\dagger)=0.0000$

Dari hasil perhitungan data diatas menunjukkan bahwa nilai probabilitas $\operatorname{Pr}(T$ $<$ †) $<0$ yaitu sebesar 1.0000 dan nilai probabilitas $\operatorname{Pr}(T>\dagger)>0$ yaitu sebesar 0,0000, maka dapat disimpulkan bahwa nilai probabilitas hitung lebih besar dari 0,05 yang menunjukkan bahwa $\mathrm{HO}$ diterima dan $\mathrm{Ha}$ diterima. Artinya terdapat perbedaan produk domestik bruto sebelum dan sesudah Ramadhan.

\section{Pembahasan}

Berdasarkan hasil pengolahan data dan pengujian hipotesis menunjukkan bahwa pertumbuhan ekonomi pada periode ramadhan memiliki dampak positif terhadap pertumbuhan ekonomi. Hal ini disebabkan faktor budaya dianggap memiliki peran yang vital terhadap pertumbuhan ekonomi. Budaya dapat menjadi pendorong atau bahkan penghambat pertumbuhan ekonomi disuatu wilayah. Apabila budaya tersebut bersifat positif maka akan mendorong pertumbuhan ekonomi kearah yang lebih baik, sedangkan budaya negatif akan menghambat perekonomian. Contoh budaya positif yang dimaksud adalah ulet, disiplin, tidak individualis dan jujur, sedangkan budaya negatif adalah malas, korupsi dan lain sebagainya. Budaya yang bersifat positif dalam Ramadhan yang dimaksud adalah ketika Ramadhan, konsumsi yang dilakukan masyarakat tidak seputar pada pribadi diri sendiri saja, namun memikirkan orang lain. Konsumsi yang dilakukan bertujuan untuk membantu sesama muslim, agar kebutuhan mereka dapat terpenuhi.

Indonesia sebagai negara muslim terbesar didunia memiliki budaya islam yang kental menjelang bulan ramadhan dan idul fitri. Bulan ramadhan dianggap bulan yang paling mulia dimana pada bulan tersebut pahala dilipat gandakan. Seperti firman Allah SWT:

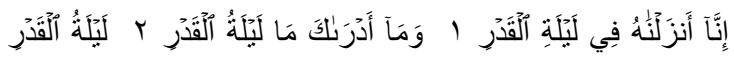

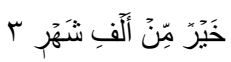


Sribanu, et al/Jurnal Ekonomi Syariah Teori dan Terapan Vol. 6 No. 5 Mei 2019: 1007-1029; PERBEDAAN KINERJA PERTUMBUHAN EKONOMI PADA KUARTAL RAMADHAN DAN RATA-RATA KUARTAL DILUAR RAMADHAN DAN IDUL FITRI

innaaa anzalnaahu fii lailatil-qodr (1) wa maaa adrooka maa lailatul-qodr (2) lailatul-qodri khoirum min alfi syahr (3)

Artinya: "Sesungguhnya Kami telah menurunkannya (Al Quran) pada malam kemuliaan. Dan tahukah kamu apakah malam kemuliaan itu. Malam kemuliaan itu lebih baik dari seribu bulan" (QS AlQadr: 1-3).

Dari firman Allah diatas menunjukkan bahwa terdapat malam kemuliaan pada bulan ramadhan yaitu malam lailatul qadr dimana pada malam tersebut lebih baik daripada seribu bulan dan pahala dilipat gandakan. Selain firman Allah diatas keutamaan bulan ramadhan yaitu sebagai bulan pengampunan dosa maghfirah seperti sabda Rasulullah SAW:

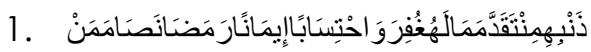
Man shooma ramadhoon iymaanaa wahtisaabaan ghufiro lahu ma taqoddama min dzanbihi

Artinya: "Barangsiapa yang berpuasa Ramadhan karena penuh keimanan dan mengharap pahala dari Allah Swt, maka diampuni dosa-dosanya yang telah lalu" (HR. Bukhari dan Muslim).

Bulan Ramadhan selain memiliki dampak psikis pada individual umat muslim, bulan Ramadhan juga dianggap memiliki dampak positif pada perekonomian di wilayah tersebut. Bulan Ramadhan mendorong umat muslim berkonsumsi lebih besar dibandingkan konsumsi diluar Ramdhan dikarenakan anjuran untuk beramal dengan cara berzakat, infaq maupun shadaqah. Selain itu, budaya mudik atau pulang ke kampung halaman juga menjadi salah Salah satu budaya umat islam untuk beramal pada bulan Ramadhan yaitu dengan cara menyediakan ta'jil untuk berbuka puasa dan makanan untuk sahur. Seperti sabda Rasulullah SAW yaitu :

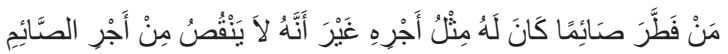

"Siapa memberi makan orang yang berpuasa, maka baginya pahala seperti orang yang berpuasa tersebut, tanpa mengurangi pahala orang yang berpuasa itu sedikit pun juga." (HR. Tirmidzi no. 807, Ibnu Majah no. 1746, dan Ahmad 5: 192. Al-Hafizh Abu Thahir mengatakan bahwa hadits ini shahih). Selain sabda Rasulullah diatas, Allah SWT menganjurkan untuk bersedekah dan melarang hambanya untuk menimbun harta yang akan berdampak pada perlambatan ekonomi. Allah SWT berfirman :

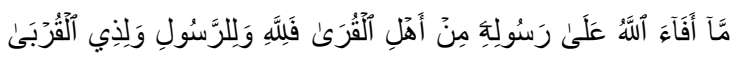

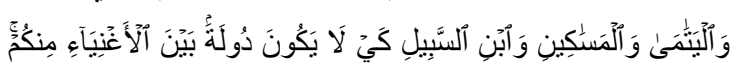

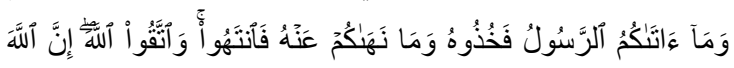

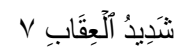

maaa afaadallohu 'alaa rosuulihii min ahlil-quroo fa lillaahi wa lir-rosuuli wa lizilqurbaa wal-yataamaa wal-masaakiini wabnis-sabiili kai laa yakuuna duulatam bainal-aghniyaaa`i mingkum, wa maaa aataakumur-rosuulu fa khuzuuhu wa maa nahaakum 'an-hu fantahuv, wattaqulloh, innalloha syadiidul-'iqoob

Artinya: "Apa saja harta rampasan (fai-i) yang diberikan Allah kepada Rasul-Nya (dari harta benda) yang berasal dari 
Sribanu, et al/Jurnal Ekonomi Syariah Teori dan Terapan Vol. 6 No. 5 Mei 2019: 1007-1029; PERBEDAAN KINERJA PERTUMBUHAN EKONOMI PADA KUARTAL RAMADHAN DAN RATA-RATA KUARTAL DILUAR RAMADHAN DAN IDUL FITRI

penduduk kota-kota maka adalah untuk Allah, untuk Rasul, kaum kerabat, anakanak yatim, orang-orang miskin dan orang-orang yang dalam perjalanan, supaya harta itu jangan beredar di antara orang-orang kaya saja di antara kamu. Apa yang diberikan Rasul kepadamu, maka terimalah. Dan apa yang dilarangnya bagimu, maka tinggalkanlah. Dan bertakwalah kepada Allah. Sesungguhnya Allah amat keras hukumannya." (QS. Al-Hashr :7)

Meningkatnya konsumsi rumah tangga khususnya umat Islam secara agregat mendorong perekonomian disuatu negara tumbuh. Permintaan barang dan jasa akan meningkat pada bulan Ramadhan sehingga menaikkan harga secara agregat, kenaikan harga akan direspon dengan meningkatnya produksi sehingga menyebabkan perekonomian di suatu negara lebih bergairah.

Hal ini berbanding terbalik dengan penelitian yang telah dilakukan oleh Campate dan Drott (2013) yang mengatakan bahwa Ramadhan memiliki dampak negatif terhadap pertumbuhan ekonomi, dikarenakan menurunya produktifitas umat muslim dibulan Ramadhan. Namun penelitian ini mendukung penelitian yang telah dilakukan oleh Wu Chongseng (2013) mengenai dampak Chinese New Year terhadap return saham dimana perayaan tahun baru China memiliki dampak positif terhadap perubahan return saham di pasar modal China. Dampak event atau hari besar berpengaruh terhadap sektor perekonomian di Negara yang merayakan hal tersebut. Hal ini juga sesuai dengan pernyataan Rosh HaShanah dan Yom Kippur, Ramadhan adalah acara keagamaan yang dapat mempengaruhi suasana hati investor dalam keputusan investasi.

\section{KESIMPULAN DAN SARAN}

Berdasarkan hasil analisis dan pembahasan, maka penelitian perbandingan kinerja pertumbuhan ekonomi pada kuartal Ramadhan dan Idul Fitri dengan kuartal selain Ramadhan dan Idul Fitri periode tahun 2008 hingga tahun 2018, dapat ditarik kesimpulan bahwa terdapat perbedaan kinerja pertumbuhan ekonomi saat dan diluar Ramadhan dan Idul Fitri periode tahun 2008 hingga tahun 2018.

\section{DAFTAR PUSTAKA}

Wu Chongseng. 2013. The Chinese New Year holiday effect: evidence from China ADR.

Sonjaya dan Wahyudi. 2016. The Ramadhan effect: Illusion or reality?. Jakarta: Departemen Manajemen, Fakultas Ekonomi Bisnis, Universitas Indonesia.

Campate dan Yanagizawa-Drott. 2013. Does Religion Affect Economic Growth and Happines? Evidence From Ramadhan. Repository: University of Zurich

Afif Abrar. 2017. Analisis Pola Perilaku Konsumsi dan Perilaku Berzakat 
Sribanu, et al/Jurnal Ekonomi Syariah Teori dan Terapan Vol. 6 No. 5 Mei 2019: 1007-1029; PERBEDAAN KINERJA PERTUMBUHAN EKONOMI PADA KUARTAL RAMADHAN DAN RATA-RATA KUARTAL DILUAR RAMADHAN DAN IDUL FITRI

Rumah Tangga Muslim pada Bulan Ramadhan (Studi Kasus di Desa Sumber Sekar Kecamatan Dau Kabupaten Malang). Malang: Universitar Brawijaya.

Sugiyono.2018. Metode Penelitian Kuantitatif. Bandung: Alfabeta

Mankiw. 2006. MAKROEKONOMI edisi 6. Indonesia: Penerbit Erlangga

Fauzia dan Riyadi. 2014. Prinsip Dasar Ekonomi Islam: Prespektif Maqashid Al Syariah. Jakarta: Prenamedia Grup

Latan, Hengky. 2014. Aplikasi Analisis Data Statistik untuk IImu Sosial Sains dengan Stata. Bandung: Alfabeta. Ekawarna. 2010. Pengantar Teori Ekonomi Makro. Jakarta: Gaung Perkasa.

Naf'an. 2014. Ekonomi Makro: Tinjauan Ekonomi Syariah. 2014. Yogyakarta: Graha IImu

Nurul Huda. 2008. Ekonomi Makro Islam: Pendekatan Teoritis. 2008. Jakarta: Kencana

Rozalinda. Ekonomi Islam: Teori dan Aplikasinya pada Aktivitas Ekonomi. 2014. Depok: PT Rajagrafindo pustaka

Nawawi Uha. 2013. Puasa Ramadhan. 2013. Jakarta: VIV Press Jakarta

Hidayat, Arif. 2016. Budaya Konsumen Bulan Ramadan Bagi Masyarakat Modern di Indonesia. Purwokerto: Institut Agama Islam Negeri

Departemen Statistik Bank Indonesia. 2016. Produk Domestik Bruto. Jakarta
Pambudi, Eko. 2013. Analisis Pertumbuhan Ekonomi dan Faktor-Faktor Yang Mempengaruhi. Semarang: Universitas Diponegoro

Paksi, Arli. (2016). Analisis Faktor-Faktor yang Mempengaruhi Pertumbuhan Ekonomi Provinsi Lampung.Lampung: Universitas Lampung

Scarnicci. 2013. Determining National Income, an Endless Journey Started 400 Years Ago. Italy: Universitas Degli

Hanantijo. Konsumsi Nasional Sebagai Penggerak Laju Pertumbuhan Ekonomi Nasional. Universitas Surakarta

Al Hadrami. Kitab Fiqih Ramadhan. Malang: Majles Taklim dan Dakwah Husnul Khatimah

Novriansyah. 2018. Pengaruh Pengangguran dan Kemiskinan Terhadap Pertumbuhan Ekonomi di Provinsi Gorontalo. Gorontalo: Ekonomi Pembangunan, Fakultas Ekonomi Bisnis, Universitas Gorontalo

Masduki. 2017. Sejarah Turunnya Al Quran. Palembang: Univesitas Islam Negeri Raden Fatah

Darman. 2013. Pengaruh Pertumbuhan Ekonomi Terhadap Tingkat Pengangguran: Analisis Hukum Okun. Jakarta: Universitas Binus Rofiuddin. 2016. Penentuan Hari dalam Sistem Kalender Hijriah 
Fahim, Khan. 2014. The Framework for Islamic Theory of Consumer Behaviour.

Al Islami, Alifudin. 2018. Analisis Reaksi Pasar Terhadap Pengumuman Right Issue Pada Emiten Saham Syariah Yang Terdaftar di Indeks Saham Syariah Indonesia (ISSI) Periode 2014-2016. Repository: Universitas Airlangga, Surabaya

Rionita. 2018. Pengaruh Pendapatan, Religiusitas, dan Tingkat Pendidikan terhadap Perilaku Konsumsi Rumah Tangga Muslim di Surabaya. Repository: Universitas Airlangga, Surabaya

Tabloid Kontan No.37. 2018. Uang Lebaran Mengalir Deras ke Daerah. Kompas Gramedia 